\title{
GAP Bölgesinde Biberlerde Fusarium oxysporum f.sp vasinfectum Kök Çürüklüğü Hastalığına Arbüsküler Mikorizal Fungusların Etkinliği
}

\author{
Ayşin BíLGiLi ${ }^{*}$, M. Ertuğrul GÜLDÜR ${ }^{2}$ \\ 'GAP Tarımsal Araştırma Enstitüsü Müdürlüğü, Bitki Sağlığı Bölümü, ŞANLIURFA \\ [ORCID: https://orcid.org/0000-0003-0801-0484] \\ ${ }^{2}$ Harran Üniversitesi, Ziraat Fakültesi, Bitki Koruma Bölümü, ŞANLIURFA \\ [ORCID: https://orcid.org/0000-0002-3374-5602] \\ *Sorumlu yazar:ahb4463@hotmail.com/aysin.bilgili@tarim.gov.tr
}

Öz

Ülkemizde biber (Capsicum annuum L.), örtü altı ve tarla yetiştiriciliği olarak iki şekilde üretimi yapılmaktadır. Biber alanlarında yaygın olarak kurumalara, kalite ve verim düşüşlerine neden olan hastalık kök ve kök boğazı çürüklüğü olup, genelde tarlada bitkilerin gelişme döneminde ortaya çıkar. Zaman içerisinde bitkide solgunluk, sararma ve kurumalar görülür. Toprak kökenli olan bu hastalık etmenlerinden özellikle Fusarium türleri bölgede yaygınlıkla görülen funguslar olarak sürvey çalışmamızda tespit edilmiştir.

Bu çalışmada; Fusarium oxysporum f.sp vasinfectum_(Fov)'a karşı mikorizal funguslardan Glomus mosseae (G.M.), Glomus intraradices (G.I.), Glomus etunicatum (G.E.) ve bu üç mikorizal fungusun karışımı olan Mikoriza Mix'in etkinliği 2016 yılında GAP Tarımsal Araştırma Enstitüsü Müdürlüğü (GAPTAEM)'nün tescilli biber çeşidi İnan-3363 üzerinde iklim odasında $25^{\circ} \mathrm{C} \pm 1$ ve $\% 60$ nem koşullarında 4 tekerrürlü olarak test edilmiştir.

Hastalık etmeni olarak ise; Güneydoğu Anadolu Bölgesi biber yetiştirilen farklı illerden toplanan ve moleküler tanısı yapılan değişik morfolojik yapı gösteren 2 adet Fusarium oxysporum f.sp vasinfectum (Fov) izolatı kullanılmıştır.

Bu çalışmada, biyolojik mücadelede kullanılmak üzere mikorizal fungusların bitkinin ve hastalık etmeninin gelişimi üzerine etkisi araştırılarak, toprağın $\mathrm{pH}, \mathrm{EC}$, bitki besin maddesi, kalite parametrelerinden bitki boyu, meyve sayısı, yaprak sayısı, gövde çapı, yeşil aksam yaş ağılık, yeşil aksam kuru ağırlık, kök uzunluğu, kök yaş ağılığı, kök kuru ağırlığı, kök kolonizasyonu, toprakta toplam spor sayımı ve hastalık şiddeti parametrelerine bakılarak etkinlikleri saptanmıştır.

Anahtar Kelimeler: Biber (Capsicum annuum), Fusarium oxysporum f.sp vasinfectum_(Fov), Arbüsküler mikorizal fungus, Kök çürüklüğü, Biyolojik mücadele

\section{The Efficiency of Arbuscular Mycorrhizal Fungi on Fusarium oxysporum f.sp vasinfectum Root Rot Diseases of Peppers in the GAP Region}

\begin{abstract}
In our country, pepper (Capsicum annuum L.), are produced in two ways; field cultivation and greenhouse. The most common diseseases in pepper cultivated areas causing declines in quality, dryness of the crop is crown and root rot disease, and it usually occurs during the growth of the plants in the field. Over time, wilt, yellowing and drying in the plants are observed. From these soilborne fungal diseases, Fusarium species were commonly existed ones in our survey study in Southeastern Anatolia Region (GAP) where this research was performed.

In this research; the effectiveness of Mycorrhizal Fungi of Glomus mosseae (GM), G. intraradices (GI), G. etunicatum (GE) and Mycorrhizal Mix (MM-mix of three kinds of this Mycorrhizal Fungi) against Fusarium oxysporum f.sp vasinfectum (Fov) were tested over Inan-3363 registered pepper variety
\end{abstract}


belong to GAP Agricultural Research Institute (GAPTAEM) in the climate room $25 \pm 1$ temperature and 60 $\%$ humidity as four replications during growing season 2016.

As disease pathogen, two isolates of Fov obtained from different peppers grown provinces in the GAP Region with different morphological structures and whose molecular analyses were made were used.

In this study, the effect of Mycorrhizal Fungi as a biological control agent on the growth of plants and disease were investigated, and their effectiveness were determined by anaysing quality parameters such as, plant height, number of leaves, wet weight and dry weight of green parts, root length, root fresh and dry weight, stem diameter, root colonization, disease severity and total spor counting in soil, soil nutirients, EC, pH.

Key Words: Pepper (Capsicum annuum L.), Fusarium oxysporum f.sp vasinfectum (Fov), Root rot, Arbuscular mycorrhizal fungi, Biological control

\section{Giriş}

Türkiye'de farklı iklim ve toprak yapısı nedeniyle birçok sebze türü yetiştirilmekte olup biber de bu sebze türlerinden biridir. Türkiye'de biber üretimi hem tarlada hem de serada yapılabilmekte; fakat iklim ve toprak isteği yanında bakım şartları ve ekim nöbeti tercihinden dolayı her bölgede yetiştirilememektedir.

Güneydoğu Anadolu Bölgesinde biber üretimi yaygın olarak tarla sebzeciliği şeklinde yapılmaktadır. Ülkemizde biber üretimi yıllık 815, 632 dekar alanda 2457,822 ton olup, örtü altı ve tarla yetiştiriciliği olarak iki şekilde üretimi yapılmaktadır. Örtü altı yetiştiriciliği Akdeniz Bölgesinde yaygındır ve daha çok taze tüketim için yapılmaktadır (Anonim, 2017). Tarla yetiştiriciliği ise, Marmara, Ege, Doğu Akdeniz ve Güney Doğu Bölgelerimizde biberin sanayi hammaddesi (pul biber, salça, konserve, turşu vb) olmaya yönelik yapılmaktadır. Güneydoğu Anadolu Bölgesinde 267,868 ton ile toplam 121.368 da alanda biber üretilmekte olup iller itibariyle ekiliş alanları bakımından başta Şanlıurfa,
Gaziantep, Kilis, Diyarbakır, Adıyaman, Mardin, Batman, Şırnak ve Siirt gelmektedir (Anonim, 2017). Şanlıurfa ilinin biber üretim potansiyeli \% 25.1 olup (Anonim, 2004), Türkiye biber üretiminin $\% \quad 6,15^{\prime}$ lik bölümünü karşılayarak ülke ekonomisine önemli katkılarda bulunmaktadır (Anonim, 2008).

Ülkemizde biber yetiştiriciliğini ve verimini olumsuz yönde etkileyen fungal hastalıklardan en önemlisi kök ve kök boğazı çürüklüğü ile solgunluk hastalıklarıdır. GAP Bölgesinde biber üretim alanlarında kök ve kök boğazı çürüklük hastalık etmenleri; Fusarium spp., Macrophomina phaseolina, Phytophthora capsici, Alternaria spp., Aspergillus niger, Aspergillus flavus, Rhizoctonia solani, Pythium spp., fungusları (Bilgili ve ark., 2015) ile Fusarium spp., Fusarium solani, Fusarium oxysporum ve Fusarium oxysporum f. sp. vasinfectum (Bilgili et al., 2017) olarak belirlenmiştir. Toprak kökenli fungal patojenler olmasından dolayı, hastalığa karşı kimyasal mücadelenin etkisi oldukça sınırlı veya etkisizdir. Bu nedenle hastalık biber 
tarımını tehdit eder hale gelmiştir. Son yıllarda biber üretiminde kök çürüklükleri nedeniyle önemli oranda verim kayıpları meydana gelmiştir. Ayrıca Fusarium oxysporum f. sp. vasinfectum hastalık etmeninin Avustralya'da sorun olduğu (Anonymous, 2014) ve özellikle dünyada tatlı biber üretim alanlarını etkilediği belirtilmiştir (Ma et al., 2001; Wang et al., 2005; Perpetua and Monares, 1998 ).

Kök ve kök boğazı çürüklük etmenleri, genelde tarlada bitkilerin gelişme döneminde ortaya çıkar. Zaman içerisinde bitkide solgunluk, sararma ve kurumalar görülür. Fungal etmen klamidospor formunda toprakta uzun yıllar canlı kalabilmektedir (Nelson et al., 1994). Toprak kökenli olan hastalık bitki artıklarında ve toprakta uzun yıllar canlı olarak kalabildiğinden şartlar hastalık için uygun olduğunda gelecek yıl ekilen yeni bitkide de solgunluk görülür. Solgunluk tüm bitkide görüldüğünden ve sulama ile diğer bitkilere yayıldığından geniş alanlarda ekonomik önemde kayıplara neden olmaktadır. Aynı alanda ve hatta aynı bitkide bu etmenler birlikte bulunabilirler.

Fusarium solgunluğu çoğunlukla asidik, kaba bünyeli topraklarda yaygındır ve daha çok nematodlarla sinergistik olarak oluşur. Bu hastalık, yüksek sıcaklık ve yağış koşullarında yaygındır. Aşırı nem ve beslenme düzensizliği bitkiyi hastalığa duyarlı kılar (Synder and Smith, 1981).

Solgunluk hastalıklarının kontrolünde toprak fumigasyonu ve ekim nöbeti önerilmektedir. Toprak fumigasyonunun ekonomik olmayışı, geniş alanlarda uygulama zorluğu ve topraktaki yararlı mikroflorayı da olumsuz etkilemesi nedeniyle kullanımı sınırlıdır. Sorgum, arpa, buğday, mısır, yonca, soya fasulyesi, üçgül gibi bitkiler ekim nöbetinde kullanılmalıdır. Diğer toprak kökenli hastalık etmenlerinde de olduğu gibi solgunluk hastalıklarına karşı da ekonomik, kesin ve pratik bir mücadele yöntemi yoktur (Yücel, 1995).

Biberlerde P. capsici, Fusarium spp, Alternaria spp., Pythium spp., Rhizoctonia solani, Macrophomina phaseoli, Aspergillus spp. nedeniyle oluşan ekonomik kaybı azaltmak için kültürel önlemler (ürün rotasyonu, sırta dikim, damla sulama sistemi, dayanıklı çeşit) ve kimyasal yöntemler uygulanmaktadır. Kimyasal yöntemler, pahalı olmaları, etkilerinin sınırlı kalması ve çevre ile insan sağlığına olumsuz etkileri nedeniyle fazla tercih edilmemektedir. Özellikle son yıllarda kimyasallar konusunda çevre bilincinin oluşması kimyasal kullanımını daha da sınırlamaktadır. Kültürel önlemler hastalığın yayılmasını önlemede etkili olmakla birlikte uygulama zorlukları mevcuttur. Hastalığa karşı mücadelede en güvenli olanı, dayanıklı çeşit ya da biyolojik mücadele etmenlerinden biyoajanların ve koruyucu etmenlerin kullanımıdır (Yücel ve Özarslandan, 2014; Akköprü ve Demir, 2005). Biyolojik mücadelede AMF funguslarından Glomus cinsi mikorizal funguslar özellikle toprak kökenli patojenlerde (Demir ve Akköprü, 2007) ve biber yetiştiriciliğinde hastalık etmenini baskıladığı için önerilmektedir (Aslanpay ve Demir, 2015). 
Arbüsküler Mikoriza fungus (AMF) oluşumunun görüldüğü bitkiler, toprak kaynaklı fungal patojenlere ve nematodlara karşı daha dayanıklı hale gelmekte böylelikle mücadelesi oldukça güç olan bu etmenlere karşı mücadelede çok önemli bir avantaj elde edilmektedir. AMF, bitki gelişimini, özellikle bitki besin maddelerinin yoğunluklarının kritik seviyelerde olduğu marjinal topraklarda ve koşullarda teşvik etmektedir. Bu teşvik, simbiozise sahip köklerin topraktan kantitatif olarak, başta fosfor (P) olmak üzere bazı makro ve mikro besin maddelerini çinko ( $\mathrm{Zn}$ ), bakır (Cu) ve demir ( $\mathrm{Fe}$ ) gibi elementleri daha iyi alabilmeleri ile açıklanmaktadır. AMF ise bitkiden bazı organik maddeleri ve karbonhidratları almaktadır (Ortaş, 2003; Song, 2005; Gosling et al., 2006). Bu yaşam şeklinde, her iki ortak da belli koşullar altında birbirlerinden faydalanmaktadırlar. Mikorizal birlik, mutualizm tipi simbiyotik bir birlik olduğundan dolayı her iki ortak için de yararlıdır (mutualistic ilişki). Bunlar kök hastalıklarına neden olmayıp, aksine konukçu bitkilerine yararlıdırlar (Agrios, 1997).

Araştırmada simbiyotik ilişkiden faydalanılarak, Fusarium oxysporum f.sp vasinfectum (Fov) kök çürüklük hastalık etmenine karşı üç farklı AMF türü ve bunların mix. karışımının biyolojik mücadelede kullanılmak üzere biyoajan olarak etkilerinin belirlenmesi amaçlanmıştır.
Materyal ve Metot

Materyal

Bitkisel materyal

$\mathrm{Bu}$ çalışmada bitkisel materyal olarak GAP Tarımsal Araştırma Enstitüsü (GAPTAEM) 'nün tescilli çeşidi iNAN-3363 F1 biber (Capsicum annuum L.) çeşidi kullanılmıştır.

\section{AMF türleri}

Çalışmada kullanılan Glomus mosseae (T.H. Nicolson\&Gerd.) Gerd.\&Trappe, Glomus intraradices (Schenck\&Smith), Glomus etunicatum Prof. Dr. Semra DEMiR (Van-Yüzüncüyıl Üniversitesi)'den temin edilmiştir. Mikorizal Mix. bu üç türün karışımından oluşturulmuştur.

\section{Patojen izolatı}

Fusarium oxysporum f.sp vasinfectum (Fov) izolatları, TAGEM-BS-13 /09-03 /02-06 ve HÜBAK- 13168 no'lu proje kapsamında 2013 ve 2014 yıllarında GAP Bölgesi biber üretim alanlarındaki sürvey çalışmasından temin edilen iki adet izolat kullanılmıştır. Elde edilen izolatların virülensliği ön çalışma ile tespit edilmiştir. Çalışmada 43-Fov (DiyarbakırHani), 183-Fov (Şanlıurfa-Birecik) olmak üzere 2 adet virülent izolat kullanılmıştır.

Fungal Patojen izolatların Moleküler Teşhisleri

Morfolojik olarak teşhisleri yapılan fungal izolatların tür seviyesinde teşhisleri moleküler çalışmalar ve 
analizleri yapıldıktan sonra belirlenmiştir. Fusarium spp. için ITS-Fuf-r primeri (AbdElsalam et al., 2003); F. oxysporum için Clox 1-2 primeri (Mule et al., 2004) ve $F$. oxysporum f.sp vasinfectum için Fov1egf$r$ primerleri (Abd-Elsalam et al., 2006) kullanılmıştır. DNA izolasyonlarında Thermo Scientific Gene JET Plant DNA Prufication Mini Kit (K0791, K0792)'in Bitki Genomik DNA Purifikasyon Protokolü kullanılmışır.

\section{Bitki yetiştirme ortamı}

Çalışmadaki biber fideleri, bir gözü $4,7 \times 4,7 \times 6,0 \mathrm{~cm}$ ebatlarındaki $45^{\prime}$ lik plastik viollerde yetiştirilmiştir. Daha sonraki aşamada (AMF, patojen ve kontrol uygulaması) ise $16 \times 18 \mathrm{~cm}$ ebatlarında plastik saksılar (2-2,5 kg.lık) kullanılmıştır. Her üç uygulamada da 1:1 oranında torf-perlit karışımından oluşan harç materyali ve üzerini kapatmak içinde vermikulit kullanılmıştır (Aslanpay ve Demir, 2015). Denemeler GAPTAEM Bitki Sağlığı Bölümü laboratuar ve iklim odasında yürütülmüştür. İklim odası; 12 saat aydınlık, 12 saat karanlık, 25-27 으 sıcaklık \% 60-65 nem koşullarında kullanılmıştır.

Metot

Fide yetiştirme ortamı ve uygulamalar

Fide yetiştirme ortamı olarak 1: 1 oranında torf + perlit, örtü kapağı olarak ise vermikulit kullanılmıştır. Harç toprağı $5 \mathrm{~cm}$ göz çapı ve $6 \mathrm{~cm}$ göz derinliğine sahip 45'lik viyollere konulmuş ve mikorizal fungus inokulasyonu yapılacak viyollere tohum yatağına $2.5 \mathrm{gr}$ inokulum ilave edilmiştir. Kontrol olarak kullanılacak viyollere ise inokulum ilave edilmemiştir. Ekim tarihinden bir gün önce biber tohumları akşamdan suda bekletilerek tohumların ekimi gerçekleştirilmiştir. Ekimi yapılacak biber tohumları, üç defa saf su ile yıkanarak, \% 2'lik NaOCl'de 5 dakika tutularak ve tekrar iki defa steril saf sudan geçirilerek yüzey dezenfeksiyonu sağlanmıştır. Viyollerde bulunan biber fideleri daha sonra $16 \times 18 \quad \mathrm{~cm} \quad(2-2,5 \quad \mathrm{~kg} . \mathrm{lık})$ ebatlarındaki plastik saksılara şaşırtılmışlardır. Saksılarda yetiştirme toprağı olarak 1:1 oranında perlit : torf karışımı kullanılmıştır. Deneme, tesadüf parselleri deneme desenine göre 4 tekerrürlü ve her tekerrürde 16 bitki olacak şekilde kurulmuştur.

Fideler 12 saat ışıklanma süresi ve $25 \pm 1{ }^{0} \mathrm{C}$ sıcaklık ve \% 60-70 orantılı nem koşullarına sahip iklim odasında yetiştirilmişlerdir. Tohumlar çimlenene kadar iki günde bir, çimlenme gerçekleştikten sonra her gün saf su ile sulanmıştır. (Vosatka and Gryndler, 1999). Deneme 8 hafta sonra sonlandırılmış ve mikorizal fungusun etkinliği, kök kolonizasyonu ve hastalık şiddeti oranları hesaplanmak suretiyle tespit edilmiştir.

Patojen inokulumunun hazırlanması ve bitkilere inokulasyonu

2013 ve 2014 yıllarında GAP Bölgesi biber üretim alanlarındaki sürvey projesi çalışmasından elde edilen virülensliği yüksek olarak test edilen ve temin edilen Fusarium oxysporum f.sp. vasinfectum izolatları steril kabin içerisinde PDA besi ortamına alınmış ve 26 o $C^{\prime}$ de çalışan 
inkübatörde 5-7 gün karanlıkta inkübasyona bırakılmıştır. Plastik saksılara şaşırtılan biber fidelerinin 5-6 tane gerçek yaprakları oluştuktan sonra patojen inokulasyonu yapılmıştır. Bu amaçla öncelikle petrilerde gelişen kültürün en uç kısmından $5 \mathrm{~mm}$ çapında miselyum diskleri alınarak, suni yapay kültür ortamı (yulaf/kepek) hazırlanıp otoklav edildikten sonra bu erlanmayerler içerisine fungusun miselleri ve diskleri atılarak $26 \pm 1{ }^{\circ} \mathrm{C}$ sıcaklıktaki inkübatörde 1 hafta-10 gün süreyle inkübasyona bırakılmıştır. Daha sonra gelişen yapay ortam saksı toprağına bulaştırılarak bitkiler viyollerden saksılara şaşırtılmıştır. Bitkiler, iklim odasında 12 saat karanlık 12 saat aydınlıkta, $25^{\circ} \mathrm{C}^{\prime}$ de tutularak patojenin gelişimi ve lezyon oluşumu günlük olarak takip edilmiştir (Ahmed et al., 2000; Alejo- Iturvide et al., 2008; Varma et al., 2009). Bu yönteme göre, PDA besi ortamında 25 o C'de 7-10 gün karanlıkta inkübatörde geliştirilen patojen izolatından 5-10 $\mathrm{mm}$ çapında parçalar kesilmiş ve yapay yulaf kültürü içerisine konulmuştur. Patojen inokulasyonu yapılacak olan bitkilerin kök çevresine inokule edilmiştir.

\section{Hastalık şiddetinin değerlendirilmesi}

Patojen inokulasyonundan itibaren 4. hafta süresince bitkilerde ortaya çıkmaya başlayan hastalık simptomları belirli aralıklarla değerlendirilerek hastalık şiddeti belirlenmeye çalışılmıştır. Buna göre Fusarium oxysporum f.sp. vasinfectum 'un neden olduğu hastalık şiddeti, patojen inokulasyonundan itibaren 4. 5. 6. ve 7. haftaların sonunda 0-4 skalası (Yao et al., 2002; Aslanpay ve Demir, 2015 modifiye edilerek) kullanılarak tespit edilmiştir. Bu skalaya göre; 0: Hiç simptom yok 1: Yaprakta küçük renk değişikliği, hafif solgunluk, deformasyon 2: Yaprakta şiddetli sararma, solgunluk, bodurluk, 3: Gövdede kararma, 4: Tam kuruma-ölü bitki olarak değerlendirilmiştir. Bu değerlendirme sonuçları aşağıdaki formül yardımıyla hesaplanarak hastalık şiddeti (\%) olarak tespit edilmiştir.

$\%$ Hastalık şiddeti= (Skala değ. $\mathrm{x}$ freakansı) + (Skala değ. $x$ frekansı)...x100/ Toplam bitki sayısı $x$ En yüksek skala değeri

\section{AMF kök kolonizasyonunun belirlenmesi}

\section{Fiksasyon ve Boyama}

Biber bitkisinin toprak üstü aksamları kesilerek kök ve kök boğazı kısmının yavaşça ve dikkatli bir şekilde topraktan ayrılması sağlanmıştır. Topraktan ayrılan kökler musluk suyu altında iyice yıkanarak köklere yapışan toprak parçacıkları temizlenmiştir. Köklerden daha sonra 1-0.5 gr'lık parçalar alınarak AFA Fiksasyon sivisına (\% 70'lik $90 \mathrm{ml}$ Alkol, $5 \mathrm{ml}$ Formaldehit ve $5 \mathrm{ml}$ Asetik asit) konmuş ve kökler boyama işlemine kadar bu sıvı içinde muhafaza edilmiştir. AFA sıvısı içinde muhafaza edilen kökler, mikorhizal fungusun varlığını ve kolonizasyon yüzdesini saptamak amacıyla trypan mavisi ile boyanmıştır. Boya olarak içerisine \% 0.4'lük Trypan mavisi bulunan laktik asit $(40 \mathrm{ml})+$ gliserin $(80 \mathrm{ml})+$ saf su $(40 \mathrm{ml})^{\prime}$ dan oluşan çözelti kullanılmıştır (Phillips and 
Hayman 1970'den modifiye edilmiştir; Read et al. 1976). Boyalı köklerdeki AMF funguslarının kolonizasyon \%'sini saptamak üzere GridLine Intersect Metodu kullanılmış (Giovanetti and Mosseae, 1980) ve mikorizal spor sayısı ise kökler trypan blue ile boyanarak Read et al. 1976'ya göre 40-100 büyütme ile ışık mikroskobu altında incelenmiştir.

\section{Mikorizaların}

etkinliğinin

değerlendirilmesi

Kök enfeksiyon yüzdesi ise yüzde hesabı kullanılarak hesaplanmıştır:

Kök enfeksiyon (\%)= ( Enfeksiyonlu kök sayısı (adet) / Toplam kök sayısı (adet) )x 100

\section{Mikoriza spor sayısı (adet/10)}

Saksılardaki torf perlit karışımı örneklerinden $10 \mathrm{~g}$ alınıp üzerine $100 \mathrm{ml}$ saf su eklenip 53-125 $\mu \mathrm{m}^{\prime}$ lik eleklerden geçirilerek ve 20 dakika 3000 rpm'de santrifüj edilmiştir. Süpernatanttan $10 \mathrm{ml}$ alınıp, \% 50'lik sakkarozla $50 \quad \mathrm{ml}^{\prime} \mathrm{e}$ tamamlanmıştır. Tekrar 20 dakika 3000 rpm'de santrifüj edilmiştir. Santrifüjlenen örneklerden $5 \mathrm{ml}$ alınıp petri içine konulduktan sonra mikroskopta 40 büyütme ile spor yoğunluğu incelenmiştir (Gerdeman ve Nicolson, 1963; Akay ve Karaarslan, 2015).

Fide morfolojik gelişim parametrelerinin belirlenmesi

Fide morfolojik gelişim parametreleri sürgün ve kök uzunlukları $(\mathrm{cm})$, kök boğazı çapı $(\mathrm{mm})$, hasattan sonra sürgün ve kök yaş ağırlıkları (g), biber fidelerinin hasadı sırasında yaprak sayısı (adet/fide) belirlenmiştir. Yaş ağırlıkları ölçülen bitkilerin kök ve yeşil aksam örnekleri kese kağıtlarına konulmuş, $70^{\circ} \mathrm{C}$ 'de 48 saat süresince etüvlerde tutularak sürgün ve kök kuru ağırlıkları belirlenmiştir (Kaçar ve İnal, 2008).

Mikro ve Makro besin elementi içeriklerinin belirlenmesi

Mikro ve makro besin elementi içerikleri bitkilerin hem kök bölgesinde hem de sürgünde ayrı ayrı belirlenmiştir. Biber bitkileri hasat edildikten sonra kurutulmuş ve öğütülmüş, öğütülen bitki örneklerinden 1'er g alınarak yakma işlemine tabi tutulmuşlardır (Jones et al., 1993). Nitrik ve perklorik asit karışımı ile yakma işleminden sonra elde edilen süzükler ICP - OES cihazında okutularak Kalsiyum (Ca), Magnezyum (Mg), Fosfor(P) ve Potasyum (K) içerikleri belirlenmiştir. Bitki örneklerinde toplam azot analizi ise Kaçar ve İnal (2008)'a göre Yakma, Destilasyon ve Titrasyon olmak üzere 3 aşamada yapılmıştır.

Mikro besin elementi içerikleri belirlenirken Jones et al., 1993'e göre, Nitrik ve perklorik asit karışımı ile yakma işleminden sonra elde edilen süzükler ICP - OES cihazında okutularak Demir (Fe), Mangan (Mn), Çinko (Zn), Sodyum (Na), Bor (B) ve Bakır (Cu) (mg/kg) içerikleri belirlenmiştir.

Yetiştirme toprağında $E C$ ve $p H^{\prime} n ı n$ belirlenmesi

Uygulama gruplarının yetiştirme ortamı tuz içerikleri ve $\mathrm{pH}^{\prime}$ sının belirlenmesi amacıyla toprak örnekleri alınmış ve çamur süzükleri elde 
edilmiştir. Kuruyuncaya kadar bekletilen topraklardan 100 gr tartılarak saf su ile satürasyon çamuru hazırlanmıştır. Hazırlanan satürasyon çamurunda $\mathrm{pH}$ ve $\mathrm{EC}$ değerleri $\mathrm{pH}$ metre ve EC metre ile belirlenmiştir.

\section{İstatistiki Değerlendirmeler}

Çalışma sonunda elde edilen veriler ANOVA istatistik analizine tabi tutulmuştur. İstatistiksel analizler için MiNITAB paket programı kullanılmış ve Tukey Çoklu Karşılaştırma Testi uygulanmıştır.

\section{Araştırma Bulguları ve Tartışma}

Hastalık Şiddeti (\%)

Mikorizal fungusların Fusarium oxysporum f.sp. vasinfectum (Fov) hastalık etmeni üzerine etkileri haftalar bazında değerlendirildiğinde hastalık şiddeti 4. haftada \% 45 oranında iken 7. haftada \% 25 olarak belirlenmiştir. Bu da haftalar ilerledikçe mikorizal fungusların etki mekanizmasının ortaya çıktığını ve bitkilerin hastalık etmenine karşı dayanıklılık mekanizmasını geliştirdiğini ortaya koymaktadır.

Farklı Arbüsküler Mikorizal Fungusların (AMF) ve bunların karışımı olan Mikorizal Mix.'in (MM) Fov'un hastalık şiddetine etkisi \% 11.107-\% 68.90 arasında değişmiştir (Çizelge 1). En yüksek hastalık şiddeti 43 Fov uygulama grubunda (\% 68.90) yani Kontrol (+) 'te tespit edilirken, en düşük hastalık şiddeti ise her iki hastalık etmeni (43 Fov-183 Fov) izolat için de Glomus etunicatum (GE)+ Patojen uygulama grubunda (sırasıyla \% 27.77- \% 11.107) olarak belirlenmiştir (Çizelge 1). Hastalık şiddeti değerlerine bakıldığında, genel olarak GE'un Fov hastalık şiddetini değişen oranlarda baskıladığı ortaya çıkmıştır. Matsubara et al. (1995), Patlıcan bitki köklerinde mikorizal fungus kolonizasyonu uygulamadan 10 hafta sonra GE ve GM için sırasıyla \% 48 ve \% 40.2 oranında olduğunu tespit ederek, AMF fungus inokulasyonuyla $V$. dahliae' nin hastalık görünümü kontrole oranla azaldığını veya geciktirildiğini belirterek bu çalışmada elde edilen sonuçlarla benzer sonuçlar elde etmişlerdir.

AMF fungusların toprak kökenli patojenler üzerindeki etkisi ve baskılama mekanizması farklı patosistemlerde de incelenmiş ve genel olarak bu simbiyotik mikroorganizmaların özellikle fungal kök patojenleri üzerinde engelleyici bir etkisinin olduğu ortaya konmuştur (Linderman, 1992; Demir ve Akköprü, 2007; Aslanpay ve Demir, 2015). İki hastalık etmeni Fov izolatları (43 Fov Kontrol + ; 183 Fov Kontrol + ) arasındaki farklılık ise; bu iki izolatın farklı illerden elde edilmesine ve izolatların virülenslik derecesinin farklı olmasına bağlanmaktadır. $\mathrm{Bu}$ nedenle bu çalışmada 43 Fov şiddetli bir izolat olarak görülmüştür. 
Çizelge 1. Farklı AMF uygulanmış ve Fov inokule edilmiş biber bitkilerinin hastalık şiddetleri (\%)

Table 1. Disease severity of the pepper plants inoculated Fov and treated with different AMF (\%)

\begin{tabular}{|c|c|c|}
\hline $\begin{array}{l}\text { Uygulamalar } \\
\text { Treatments }\end{array}$ & $\begin{array}{l}\text { Hastalık şiddeti } \\
\text { Disease severity } \\
43 \text { Fov }(\%)^{*}\end{array}$ & $\begin{array}{l}\text { Hastalık şiddeti } \\
\text { Disease severity } \\
183 \text { Fov }(\%)^{* *}\end{array}$ \\
\hline Kontrol (-) & $0.00 \mathrm{~b}$ & $0.00 \mathrm{~b}$ \\
\hline Kontrol (+) & $68.90 a$ & $55.165 \mathrm{a}$ \\
\hline G. mosseae + Patojen & $47.22 \mathrm{ab}$ & $38.72 a b$ \\
\hline G. intraradices + Patojen & $49.99 a b$ & $22.22 \mathrm{ab}$ \\
\hline G. etunicatum + Patojen & $27.77 \mathrm{ab}$ & $11.107 \mathrm{~b}$ \\
\hline Mikorizal Mix + Patojen & $68.75 \mathrm{a}$ & $29.165 a b$ \\
\hline
\end{tabular}

AMF Kök Kolonizasyonunun Belirlenmesi (\%)

Grid-Line intersect metodu kullanılarak yapılan değerlendirmelerde biber bitkisi köklerindeki AMF türlerinin ve bunların Mix. karışımının kolonizasyon oranları 43 Fov için; \% 80- \% 33.33 arasında, 183 Fov için ise \% 73.33- \% 33.33 arasında değiştiği tespit edilmiştir (Çizelge 2). Çalışma kapsamında yer alan uygulama grupları arasında en yüksek kolonizasyon oranı her iki hastalık etmeni izolat için de (43 Fov-183 Fov) G. etunicatum + Patojen'in yer aldığı uygulama grubunda sırasıyla $\% 80$ ve $\%$ 73.33 olarak tespit edilmiştir.

Tutar (2014) yaptığı çalışmayla Fom'un patıcan bitkilerinde oluşturduğu solgunluğu GE \% 79 oranında engellediğini, patojenin iletim demetlerinde ilerlemesini en fazla engelleyen funguslar ise GM, GE ve GF (\% 32-39) olduğunu belirterek üç AMF ile yaptığımız deneme sonuçlarıyla benzer GE'nin daha etkili olduğunu belirtmiştir. V. dahliae'nın patıcan bitkilerinde oluşturduğu solgunluğu (\% 32-53) ve patojenin iletim demetlerinde ilerlemesini (\% 22-37) bu AMF funguslarının engellediğini bildirmiştir (Tutar, 2014).

Arbüsküler Mikorizal Fungusların kök kolonizasyonları toprak kökenli patojenler tarafından nasıl etkilendiği literatürlerde de netlik kazanmamıştır. Zambolim and Schenck (1983), Hassan Der et al.,(1997) ve Akköprü and Demir (2005), AMF funguslarının çeşitli konukçularda ve farklı hastalık etmeni patojenler tarafından nasıl etkilendiğini ve kök kolonizasyonlarının azaltıldığını belirlemişlerdir. Buna karşılık; Caron et al., (1985), Özgönen ve ark. (1999), Yücel ve ark. (2001) ve Arslanpay ve Demir (2015) ise yapmış oldukları çalışmalarla AMF funguslarının kök kolonizasyonunun istatistiki açıdan önemli düzeyde etkilenmediğini belirlemişlerdir. Çalışmamı sonucunda ise AMF kök kolonizayonunun Fusarium oxysporum f.sp. vasinfectum (Fov) bakımından istatistiki açıdan önemli düzeyde etkilendiği tespit edilmiştir. 
Çizelge 2. Farklı AMF uygulanmış ve Fov inokule edilmiş biber bitkisi köklerinin kolonizasyon oranları (\%) Table 2. Colonization rates (\%) of the pepper plant roots inoculated and Fov treated with different AMF

\begin{tabular}{|c|c|c|}
\hline $\begin{array}{l}\text { AMF türleri } \\
\text { AMF Species }\end{array}$ & $\begin{array}{l}\text { Kök kolonizasyonu } \\
\text { Root colonization } \\
43 \text { Fov }(\%)^{\beta^{*}}\end{array}$ & $\begin{array}{l}\text { Kök kolonizasyonu } \\
\text { Root colonization } \\
183 \text { Fov }(\%)^{\beta^{*}}\end{array}$ \\
\hline Kontrol (-) & $0.00 b$ & $0.00 \mathrm{~b}$ \\
\hline G. mosseae + Patojen & $35.00 \mathrm{ab}$ & $53.33 \mathrm{ab}$ \\
\hline G. intraradices +Patojen & $46.67 \mathrm{ab}$ & $56.67 \mathrm{ab}$ \\
\hline G. etunicatum + Patojen & $80.00 \mathrm{a}$ & $73.33 \mathrm{a}$ \\
\hline Mikorizal Mix + Patojen & $70.00 \mathrm{ab}$ & $70.00 \mathrm{ab}$ \\
\hline G. mosseae & $63.33 \mathrm{ab}$ & $63.33 \mathrm{ab}$ \\
\hline G. intraradices & $50.00 \mathrm{ab}$ & $50.00 a b$ \\
\hline G. etunicatum & $33.33 \mathrm{ab}$ & $33.33 \mathrm{ab}$ \\
\hline Mikorizal Mix & $65.00 \mathrm{ab}$ & $65.00 a b$ \\
\hline
\end{tabular}

Mikoriza Spor Sayımı (adet/10)

Farklı iki Fov hastalık etmeni izolat üzerine, mikorizal fungus uygulama gruplarının etkilerinin incelendiği toplam mikoriza spor sayısına etkisi en yüksek 13.667 ile en düşük 3.667 arasında değişmiştir. En yüksek Mikorizal Mix+ 43 Fov (13.667) muamele grubuyla, Mikorizal Mix- M.M (12.667) muamele grubunda tespit edilirken, en düşük her iki Fov izolatı için de G. mosseae- G.M. muamele grubunda (3.667) belirlenmiştir. Her iki patojen izolat üzerinde de (43-Fov; 183-Fov) en yüksek değerler sırasıyla M.M.+ Patojen (13.66711.667) ve M.M. (12.667-12.667) uygulamalarından elde edilmiştir. Çalışmamız sonuçlarında mikoriza spor sayımı, 43 Fov izolatı bakımından istatistiki açıdan 0.05 önem seviyesinde önemli bulunurken 183 Fov izolatı için istatistiki açıdan önemli düzeyde etkilenmediği görülmekte olup, genel olarak artış göstermiştir. íki izolat arasındaki bu fark izolatların elde edildiği illerin farklı olmasına ve virülenslik derecelerine bağlanmaktadır. 43 Fov hastalık etmeni patojenin daha virülent olduğu hastalık şiddeti oranlarında da \% olarak belirlenmiştir (Çizelge 1, Çizelge 3).

Mikro ve Makro Besin Elementi içeriklerinin Belirlenmesi

Yapılan uygulamalarda mikorizal fungusların $\mathrm{Fe}, \mathrm{Na}, \mathrm{B}, \mathrm{Cu}, \mathrm{Mn}, \mathrm{Zn}$ mikro bitki besin maddelerinin alımları üzerine etkisinin istatistiki açıdan önemli olmadığı belirlenmiştir.

Üç farklı AMF ve bunların karışımı olan Mikorizal Mix. uygulamasının yapıldığı ve iki farklı hastalık etmeni patojenin (43Fov, 183-Fov) inokule edildiği biber fidelerinde, makro besin elementi içeriklerinden \% Azot oranına baktığımızda genel olarak kontrol 
bitkilerine oranla arttığı tespit edilmiş olup; her iki patojen için de en yüksek değer G.M. (5.961-5.962) uygulamasından, en düşük değer ise
M.M. (2.563) uygulamasından elde edilmiş ve 43-Fov patojeni için istatistiki açıdan $\mathrm{P}<0.05^{\prime}$ e göre de önemli bulunmuştur (Çizelge 4)

Çizelge 3. Farklı AMF uygulanmış ve Fov inokule edilmiş biber bitkisi köklerinin mikoriza toplam spor sayımı (adet/10)

Table 3. Mycorrhizal total spore count of the pepper plant roots inoculated Fov and treated to different AMF (adet/10)

\begin{tabular}{|c|c|c|}
\hline Uygulamalar- Treatments & 43 Fov $^{*}$ & 183 Fov $^{\text {ns }}$ \\
\hline Kontrol (-) & $0.00 \mathrm{~b}$ & $0.00 \mathrm{a}$ \\
\hline G. mosseae & $3.667 \mathrm{ab}$ & $3.667 \mathrm{a}$ \\
\hline G. intraradices & $7.667 \mathrm{ab}$ & $7.667 \mathrm{a}$ \\
\hline G. etunicatum & $9.667 \mathrm{ab}$ & $9.667 \mathrm{a}$ \\
\hline Mikorizal Mix & $12.667 \mathrm{ab}$ & $12.667 \mathrm{a}$ \\
\hline G. mosseae + Patojen & $8.667 \mathrm{ab}$ & $8.667 \mathrm{a}$ \\
\hline G. intraradices+ Patojen & $8.000 \mathrm{ab}$ & $11.333 \mathrm{a}$ \\
\hline G. etunicatum+ Patojen & $8.333 \mathrm{ab}$ & $8.000 \mathrm{a}$ \\
\hline Mikorizal Mix+ Patojen & $13.667 \mathrm{a}$ & $11.667 \mathrm{a}$ \\
\hline
\end{tabular}

Çizelge 4. Farklı AMF uygulanmış ve Fov inokule edilmiş biber fidelerinin makro besin elementlerinden azot içerikleri (\%)

Table 4. Nitrogen content (\%) from macro nutrients of the pepper seedlings inoculated Fov and treated with different $A M F$

\begin{tabular}{|c|c|c|}
\hline $\begin{array}{l}\text { Uygulamalar } \\
\text { Treatments }\end{array}$ & $\begin{array}{l}43 \text { Fov- } \\
\% \text { Azot (N) }\end{array}$ & $\begin{array}{l}183 \text { Fov- } \\
\% \text { Azot }(\mathrm{N})\end{array}$ \\
\hline Kontrol (-) & $3.606 \mathrm{ab}$ & $3.606 \mathrm{a}$ \\
\hline Kontrol (+) & $2.861 \mathrm{~b}$ & $4.465 \mathrm{a}$ \\
\hline G.M.+ Patojen & $2.829 \mathrm{~b}$ & $4.936 \mathrm{a}$ \\
\hline G.İ.+ Patojen & $4.066 a b$ & $4.665 \mathrm{a}$ \\
\hline G.E.+ Patojen & $3.167 b$ & $3.853 \mathrm{a}$ \\
\hline M.M.+ Patojen & - & $3.874 \mathrm{a}$ \\
\hline G.M. & $5.961 \mathrm{a}$ & $5.962 \mathrm{a}$ \\
\hline G.ì. & $3.380 \mathrm{ab}$ & $3.381 \mathrm{a}$ \\
\hline G.E. & $2.845 \mathrm{~b}$ & $2.845 a$ \\
\hline M.M. & $2.563 \mathrm{~b}$ & $2.563 \mathrm{a}$ \\
\hline
\end{tabular}

Muamele gruplarının farklılıklarına Makro besin elementlerinden Fosfor miktarları açısından baktığımızda ise her iki patojen de (43-Fov ve 183-Fov hastalık 
etmenleri) en yüksek değerler sırasıyla G.M+ Patojen (72.647-71.327) ve en düşük değer G.E. (34.520-34.520) olarak tespit edilmiştir. Potasyum miktarları açısından ise her iki patojen için de en yüksek 187.30 ile M.M. muamele grubunda, en düşük 46.20 G.E. muamele grubunda belirlenmiş olup, istatistiki olarak da $(P<0.01)$ önem seviyesine göre potasyum (K) ve fosfor $(P)$ bitki besin elementleri açısından uygulamalar arasındaki farklılık önemli bulunmuştur (Çizelge 5).

Çizelge 5. Farklı AMF uygulanmış ve Fov inokule edilmiş biber fidelerinin makro besin elementlerinden fosfor $(\mathrm{P})$ ve potasyum $(\mathrm{K})$ içerikleri (ppm)

Table 5. Phosphorus $(P)$ and potassium (K) contents from macro nutrients of the pepper seedlings inoculated Fov and applied with different AMF (ppm)

\begin{tabular}{|c|c|c|}
\hline \multicolumn{3}{|c|}{ Bitki besin elementleri - Plant nutrient elements } \\
\hline Uygulamalar-Treatments & Fosfor $(\mathrm{P})^{* *}$-Phosphorus & Potasyum $\left(\mathrm{K}^{* *}-\right.$ Potassium \\
\hline Kontrol (-) & $69.595 \mathrm{a}$ & $75.70 \mathrm{~cd}$ \\
\hline Kontrol (+) & $72.463 \mathrm{a}$ & $115.50 \mathrm{abcd}$ \\
\hline G.M.+ 43 Fov & 72.647 a & $140.60 \mathrm{ab}$ \\
\hline G.I. +43 Fov & 69.953 a & $133.80 \mathrm{abc}$ \\
\hline G.E. + 43 Fov & $51.713 a b$ & $67.22 \mathrm{~cd}$ \\
\hline M.M. + 43 Fov & 68.223 a & $89.40 \mathrm{abcd}$ \\
\hline G.M. & $64.197 \mathrm{a}$ & $70.88 \mathrm{~cd}$ \\
\hline G.í. & $65.173 \mathrm{a}$ & $73.70 \mathrm{bcd}$ \\
\hline G.E. & $34.520 \mathrm{~b}$ & $46.20 \mathrm{~d}$ \\
\hline M.M. & 64.377 a & $187.30 \mathrm{a}$ \\
\hline \multicolumn{3}{|c|}{ Bitki besin elementleri- Plant nutrient elements } \\
\hline Uygulamalar -Treatments & Fosfor $(\mathrm{P})^{* *}$-Phosphorus & Potasyum $(\mathrm{K})^{* *}$-Potassium \\
\hline Kontrol (-) & $69.595 \mathrm{ab}$ & $75.70 \mathrm{bc}$ \\
\hline Kontrol (+) & $78.300 \mathrm{a}$ & $121.50 \mathrm{~b}$ \\
\hline G.M.+ 183 Fov & $71.327 a b$ & $69.40 \mathrm{bc}$ \\
\hline G.i. + 183 Fov & $70.037 a b$ & $98.20 \mathrm{bc}$ \\
\hline G.E. + 183 Fov & $55.860 \mathrm{~b}$ & $78.00 \mathrm{bc}$ \\
\hline M.M. + 183 Fov & - & - \\
\hline G.M. & $64.197 a b$ & 70.88 bc \\
\hline G.i. & $65.173 a b$ & $73.70 \mathrm{bc}$ \\
\hline G.E. & $34.520 \mathrm{c}$ & $46.20 \mathrm{c}$ \\
\hline M.M. & $64.377 a b$ & $187.30 \mathrm{a}$ \\
\hline
\end{tabular}

Mikorizal yaşam büyük ölçüde bitkifungus arasındaki besin alışverişine dayanan ve karşılıklı beslenme ilişkisi içinde yürüyen bir simbiyotik yaşam şeklidir. Bu konuda yapılan akademik çalışmaların çoğu bitki faydasına olan beslenme yönünü ele almışlar ve bu konuya dikkati çekerek Arbüsküler 
Mikorizal bitkilerin daha iyi geliştiğini ifade etmişlerdir (Hayman, 1982; Marschner, 1995; Ortaş, 1998; Ortaş, 2003). Bu çalışmanın amaçlarından bir tanesi de bu beslenmenin özellikle bitki açısından avantajlarını ortaya koymaktır. Nitekim gerek morfolojik parametreler ve gerekse besin elementi içeriği açısından mikorizal biber bitkilerinin mikorizal olmayanlara göre daha teşvik edildiği ve söz konusu parametre değerlerinin arttığı belirlenmiştir (Çizelge 4, 5, 7, 8, 9 ve 10). Özellikle hastalık etmenlerine karşı bitkinin oluşturduğu dayanıklılık mekanizmasının teşvikinde ve gelişmesinde rol oynayan Potasyum (K) değerlerinin bu çalışmada genel olarak yüksek oluşu da bu olguyu desteklemektedir. Bu çalışmada elde edilen sonuçlar diğer çalışmalarla paralellik göstermiş (Yücel ve ark., 2001; Demir, 2012; Aslanpay ve Demir, 2015), mikorizal fungusların bitkinin besin durumunu teşvik ettiği ve hastalık etmenlerine karşı biyolojik koruyucu etmen olarak rol oynadığı tespit edilmiştir.

Yetiştirme Toprağında EC ve $p H^{\prime}$ nın Belirlenmesi

Çalışma kapsamında yer alan GM, Gi, $\mathrm{GE}, \mathrm{MM}$ biber yetiştirilen toprakların $\mathrm{pH}$ ve tuz içeriğine olan etkileri de araştırılmıştır. Uygulama gruplarında yer alan toprak örneklerinin $\mathrm{pH}$ değerleri uygulamalara göre 5.97-6.70 arasında değişmiştir (Çizelge 6). Genel olarak biber yetiştiriciliği yapılan toprakların en uygun toprak $\mathrm{pH}$ 'sı optimum 5.6-6.8 arasında olması gerektiği bildirilmiştir (Arslanpay ve Demir, 2015). Elde ettiğimiz sonuçlara göre uygulamalarda yer alan tüm mikorizal fungusların hastalık etmeni patojenler ile birlikte verildiğinde genel olarak toprak $\mathrm{pH}^{\prime}$ sını yükselttiği görülmüştür. Toprak $\mathrm{pH}$ değerinin en uygun olduğu uygulama; 43-Fov patojen izolatı için GE + 43-Fov (6.70) ve M.M. uygulamalarının (6.54) yer aldığı muamele gruplarında tespit edilmiştir. 183-Fov patojen izolatı için ise M.M. uygulamasında (6.54) elde edilmiştir ve istatistiki olarak da $P<0.05$ önem seviyesinde önemli bulunmuştur. Tuz içerikleri açısından ise uygulamalar arasında farklılık tespit edilmemiş olup, en yüksek tuz içeriği 43-Fov patojen izolatı için G.i (0.49) ve G.M (0.44) olarak; 183-Fov patojen izolatı için ise G.i (0.49) ve G.M+ 183-Fov

uygulamalarından elde edilmiştir (Çizelge 6). Gülser ve ark. (2014) ile Aslanpay ve Demir (2015) yetiştirme ortamlarındaki tuzluluğun göstergesi olan EC (Elektriksel Iletkenlik) değerlerinin Potasyum, Salsilik asit ve Humik Asit kombinasyon uygulamalarında yükseldiği ve bunun da bitkilerdeki hastalık şiddetini artırdığını ifade etmişlerdir. Bu çalışmada da genel olarak AMF uygulanan bitkilerde tuz içeriği kontrole oranla artmakla beraber, bu artışın Hastalık Şiddetine ve Potasyum miktarına yansıması negatif yönde olmuştur (Çizelge 1 ve Çizelge 5). 
Çizelge 6. Farklı AMF uygulanmış ve Fov inokule edilmiş biber fidelerine ait toprakların pH değerleri ve tuz (EC) içerikleri

Table 6. The $\mathrm{pH}$ values and Salt (EC) contents of soils of the pepper seedlings inoculated Fov and applied with different $A M F$

\begin{tabular}{|c|c|c|c|c|}
\hline Uygulamalar-Treatments & $\mathrm{EC}(\mu \mathrm{S} / \mathrm{cm})^{\mathrm{ns}}$ & & $\mathrm{pH}^{\mathrm{ns}}$ & \\
\hline Kontrol (-) & 0.31 & $\mathrm{a}$ & 6.26 & a \\
\hline Kontrol (+) & 0.27 & $a$ & 6.03 & a \\
\hline G.M.+ 43 Fov & 0.35 & $\mathrm{a}$ & 6.34 & a \\
\hline G.I.t+ 43 Fov & 0.34 & $a$ & 6.21 & a \\
\hline G.E.+ 43 Fov & 0.23 & $\mathrm{a}$ & 6.70 & a \\
\hline M.M.+ 43 Fov & 0.38 & $a$ & 6.54 & a \\
\hline G.M. & 0.44 & $a$ & 6.22 & a \\
\hline G.i. & 0.49 & $a$ & 5.97 & a \\
\hline G.E. & 0.27 & $a$ & 6.08 & a \\
\hline M.M. & 0.26 & $a$ & 6.54 & $a$ \\
\hline Uygulamalar-Treatments & $\mathrm{EC}(\mu \mathrm{S} / \mathrm{cm})^{\mathrm{ns}}$ & & $\mathrm{pH}^{*}$ & \\
\hline Kontrol (-) & 0.31 & $a$ & 6.26 & $a b$ \\
\hline Kontrol (+) & 0.27 & $\mathrm{a}$ & 5.83 & $b$ \\
\hline G.M.+ 183 Fov & 0.46 & $\mathrm{a}$ & 6.09 & $a b$ \\
\hline G.I.+ 183 Fov & 0.36 & $\mathrm{a}$ & 6.37 & $a b$ \\
\hline G.E.+ 183 Fov & 0.26 & $a$ & 6.12 & $a b$ \\
\hline M.M.+ 183 Fov & 0.34 & $\mathrm{a}$ & 6.38 & $a b$ \\
\hline G.M. & 0.44 & a & 6.22 & $a b$ \\
\hline G.i. & 0.49 & $\mathrm{a}$ & 5.97 & $a b$ \\
\hline G.E. & 0.27 & $\mathrm{a}$ & 6.08 & $a b$ \\
\hline M.M. & 0.26 & $a$ & 6.54 & $a$ \\
\hline
\end{tabular}

Fide Morfolojik Gelişim Parametreleri

Uygulanan farklı mikorizal fungusların (G. mosseae; G. intraradices; $G$. etunicatum) ve bu mikorizal fungus türlerinin karışımlarının (Mix) hastalık etmeni uygulanmış biber fideleri üzerine etkileri farklı parametreler (Kök Boyu, Sürgün Boyu, Kök Boğaz çapı, Yaprak Sayısı, Sürgün Yaş Ağırlık, Sürgün Kuru Ağırlık, Kök Yaş Ağırlık ve Kök Kuru Ağırlık) için istatistiksel olarak ( $p<0.05$ ve $p<0.01$ seviyede) One-Way Anova yöntemi ile MiNiTAB programında yapılmıştır. Sonuçlar Çizelge 7- 8- 910 'da verilmiştir; buna göre kök boyu ve yaprak sayısı yönünden incelenen mikorizal fungusların istatistiksel olarak iki farklı patojen izolatı için de (43-Fov, 183-Fov) önemsiz bulunurken ( $p>0.05$ ); Sürgün Yaş ağırlık, Kök Yaş ve Kuru ağırlıkları için istatistiksel olarak önemli ( $p<0.05)$ ve çok önemli $(p<0.01)$ bulunmuştur. Ayrıca Sürgün Boyu ve Kök Boğazı çapı için de her iki farklı patojen izolatı için de istatistiksel olarak önemli 
( $p<0.05)$ ve çok önemli $(p<0.01)$ bulunmuştur.

Biber fidelerinin 43-Fov patojen izolatı için sürgün boyu, kök boyu ve kök boğazı çapında en yüksek değerleri Mikorizal Mix uygulama grubunda sırasıyla 39.88 $\mathrm{cm}, 33.45 \mathrm{~cm}$ ve $3.81 \mathrm{~cm}$ olarak elde edilirken, yaprak sayısı için ise 30, 62 adet ile $\mathrm{GM}+43-F o v$ muamele grubunda elde edilmiştir. 183-Fov patojen izolatı için ise en yüksek değerleri sürgün boyu (39.92 cm) G.E.+183-Fov, kök boyunu ise (33.51 cm) G.E. uygulama gruplarında; kök boğazı çapı ve yaprak sayısını ise sırasıyla $4.12 \mathrm{~cm}$ ve 39.91 adet olarak G.M.+ 183-Fov uygulama grubunda tespit edilmiştir (Çizelge 7 ve Çizelge 9).

Biber fidelerinin 43-Fov ve $183-F o v$ her iki patojen izolatı için de sürgün yaş ve kuru ağırlık ile kök yaş ve kuru ağırlık için en yüksek değerleri mikorizal fungusların tek başına muamele yapıldığı uygulama gruplarında tespit edilmiş olup; sürgün yaş ağırlık G.M (49.50), sürgün kuru ağırlık G.E (4.98) kök kuru ağırık G.i (1.29) ve kök yaş ağırlık G.E. (11.54) olarak elde edilmiştir (Çizelge 8 ve Çizelge 10).

Demir ve arkadaşları (2012) yaptığı çalışmanın sonuçları bu sonuçlarla paralellik göstermiş; mikorizal fungusların bitki gelişim parametrelerini olumlu yönde etkilediklerini, AMF'nin hümik asit ve peynir altı suyu gibi farklı uygulamalarla birlikte kullanıldıklarında toprak kökenli patojen olan Verticillium dahliae'nın hastalık şiddetini \% 40-\% 70.5 oranında baskıladıklarını tespit etmişlerdir.

Çizelge 7. Farklı AMF uygulanmış ve 43-Fov patojeni inokule edilmiş biber fidelerinin sürgün boyu $(\mathrm{cm})$, kök boyu (cm), kök boğazı çapı $(\mathrm{cm})$ ve yaprak sayısı (adet) değerleri

Table 7. The shoot length (cm), root length (cm), root neck diameter $(\mathrm{cm})$ and number of leaves (piece) of values of the pepper seedlings applied with different AMF and inoculated 43-Fov pathogen

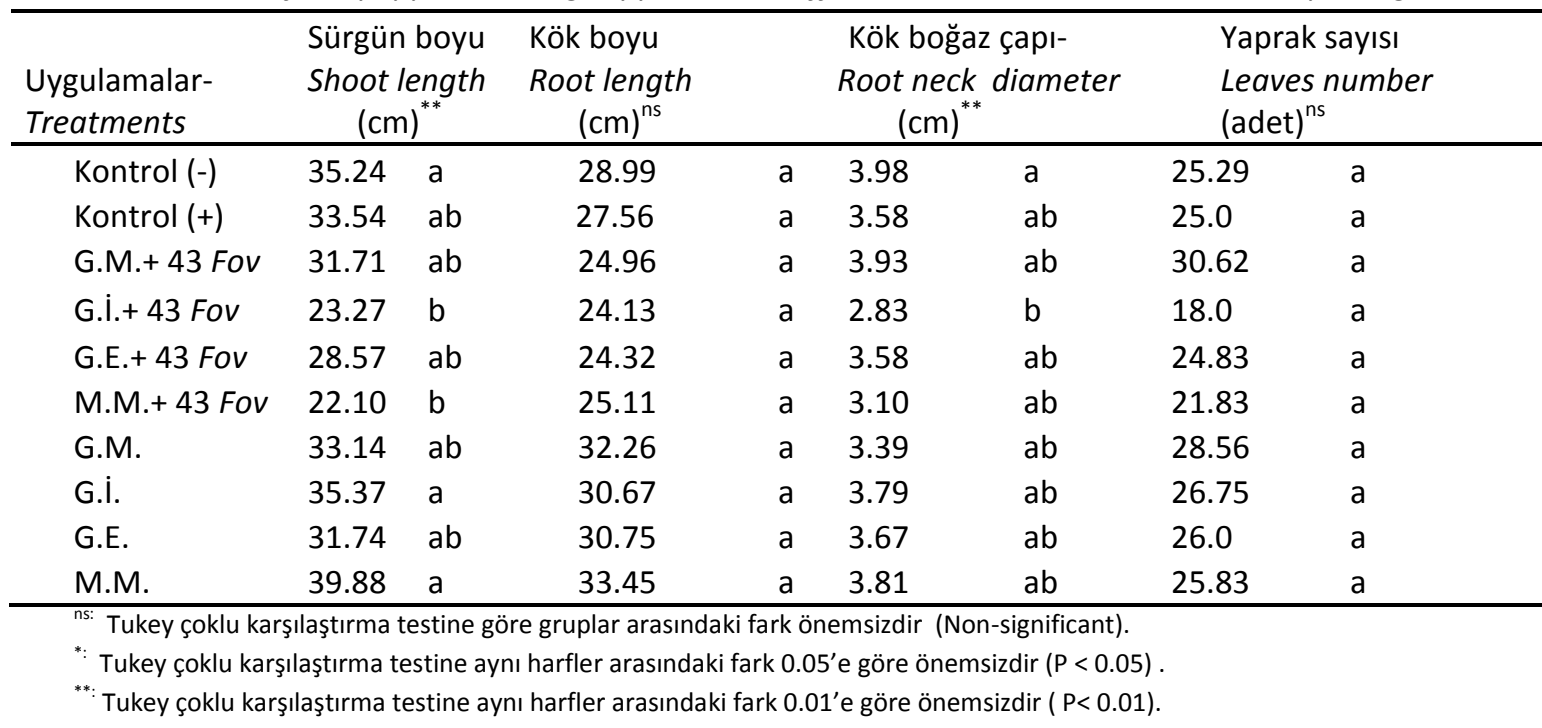


Çizelge 8. Farklı AMF uygulanmış ve 43-Fov patojeni inokule edilmiş biber fidelerinin sürgün yaş ve kuru ağırlığı (g), kök yaş ve kuru ağırlığı (g) değerleri

Table 8. Fresh and dry weight of the shoot $(\mathrm{g})$, fresh and dry weight of the root $(\mathrm{g})$ of values of the pepper seedlings applied with different AMF and inoculated 43-Fov pathogen

\begin{tabular}{|c|c|c|c|c|c|c|c|c|}
\hline \multirow{2}{*}{$\begin{array}{l}\text { Uygulamalar- } \\
\text { Treatments } \\
\text { Kontrol (-) }\end{array}$} & \multicolumn{2}{|c|}{$\begin{array}{l}\text { Sürgün yaş } \\
\text { ağırlık-Shoot fresh } \\
\text { weight }(\mathrm{g})^{* *}\end{array}$} & \multicolumn{2}{|c|}{$\begin{array}{l}\text { Sürgün kuru } \\
\text { ağırlık - Shoot dry } \\
\text { weight }(\mathrm{g})^{\mathrm{ns}}\end{array}$} & \multicolumn{2}{|c|}{$\begin{array}{l}\text { Kök yaş } \\
\text { ağırlık-Root fresh } \\
\text { weight }(\mathrm{g})^{* *}\end{array}$} & \multicolumn{2}{|c|}{$\begin{array}{l}\text { Kök kuru } \\
\text { ağırlık-Root dry weight } \\
\text { (g) }\end{array}$} \\
\hline & 47.28 & a & 4.25 & a & 6.26 & bc & 0.87 & $a b$ \\
\hline Kontrol (+) & 45.53 & $a b$ & 3.34 & a & 3.84 & bc & 0.46 & $b$ \\
\hline G.M.+ 43Fov & 52.85 & $\mathrm{a}$ & 4.54 & a & 7.02 & $a b c$ & 0.78 & $a b$ \\
\hline G.I. +43 Fov & 19.91 & $b$ & 7.70 & a & 1.19 & c & 0.28 & $b$ \\
\hline G.E.+ 43 Fov & 36.68 & $a b$ & 3.38 & a & 7.07 & $a b c$ & 0.68 & $a b$ \\
\hline M.M.+43Fov & 19.79 & $a b$ & 1.59 & a & 2.66 & bc & 0.24 & $b$ \\
\hline G.M. & 49.50 & $\mathrm{a}$ & 4.45 & a & 5.85 & bc & 0.75 & $a b$ \\
\hline G.i. & 42.10 & $a b$ & 4.15 & a & 7.95 & $a b$ & 1.29 & a \\
\hline G.E. & 47.60 & $\mathrm{a}$ & 4.98 & a & 11.54 & a & 1.15 & a \\
\hline M.M. & 35.91 & $a b$ & 3.27 & $\mathrm{a}$ & 8.34 & $a b$ & 0.76 & $a b$ \\
\hline
\end{tabular}

Çizelge 9. Farklı AMF uygulanmış ve 183-Fov patojeni inokule edilmiş biber fidelerinin sürgün boyu $(\mathrm{cm})$, kök boyu $(\mathrm{cm})$, kök boğazı çapı $(\mathrm{cm})$ ve yaprak sayısı (adet) değerleri

Table 9. The shoot length $(\mathrm{cm})$, root length $(\mathrm{cm})$, root neck diameter $(\mathrm{cm})$ and number of leaves (piece) of values of the pepper seedlings applied with different AMF and inoculated 183-Fov pathogen

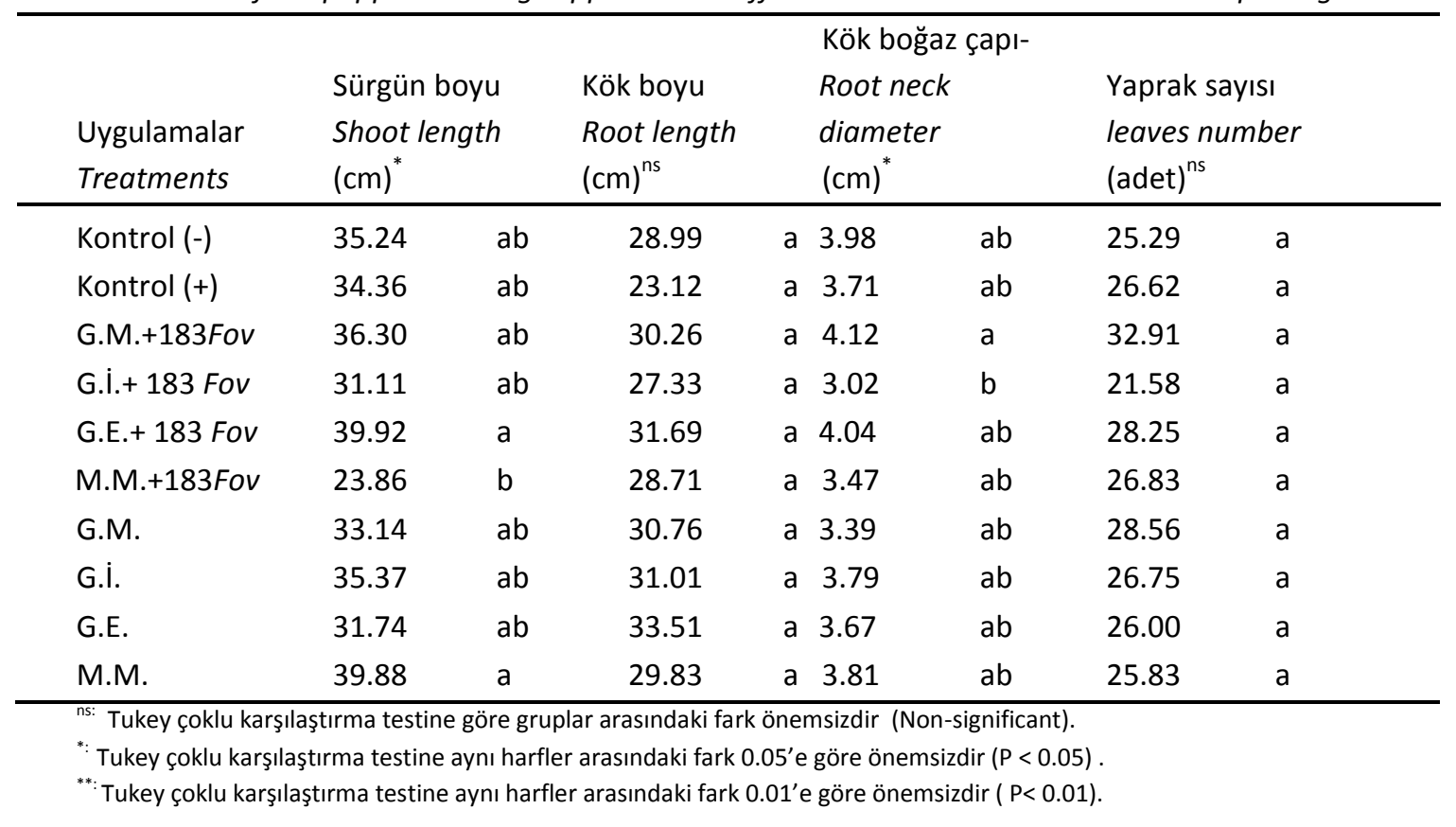


Çizelge 10. Farklı AMF uygulanmış ve 183-Fov patojeni inokule edilmiş biber fidelerinin sürgün yaş ve kuru ağırlığı (g), kök yaş ve kuru ağırlığı (g) değerleri

Table 10. Wet and dry weight of the shoot $(\mathrm{g})$, wet and dry weight of the root $(\mathrm{g})$ of values of the pepper seedlings applied with different AMF and inoculated 183-Fov pathogen

\begin{tabular}{|c|c|c|c|c|c|c|c|c|}
\hline \multirow{2}{*}{$\begin{array}{l}\text { Uygulamalar- } \\
\text { Treatments } \\
\text { Kontrol (-) }\end{array}$} & \multicolumn{2}{|c|}{$\begin{array}{l}\text { Sürgün yaş } \\
\text { ağırlık-Shoot } \\
\text { fresh weight } \\
\qquad(\mathrm{g})^{\text {ns }}\end{array}$} & \multicolumn{2}{|c|}{$\begin{array}{l}\text { Sürgün kuru } \\
\text { ağırlık- Shoot } \\
\text { dry weight }(\mathrm{g})^{\mathrm{ns}}\end{array}$} & \multicolumn{2}{|c|}{$\begin{array}{l}\text { Kök yaş } \\
\text { ağırlık- Root } \\
\text { fresh weight } \\
\text { (g) }\end{array}$} & \multicolumn{2}{|c|}{$\begin{array}{l}\text { Kök kuru } \\
\text { ağırlık-Root } \\
\text { dry weight } \\
\text { (g) }\end{array}$} \\
\hline & 47.28 & $a$ & 4.25 & $a$ & 6.26 & bc & 0.87 & $a b$ \\
\hline Kontrol (+) & 49.01 & $\mathrm{a}$ & 3.54 & a & 4.40 & c & 0.62 & $\mathrm{~b}$ \\
\hline G.M.+183Fov & 52.41 & a & 4.64 & a & 5.06 & $\mathrm{bc}$ & 0.77 & $a b$ \\
\hline G.I. +183 Fov & 34.89 & $\mathrm{a}$ & 2.72 & a & 5.48 & $\mathrm{bc}$ & 0.60 & $\mathrm{~b}$ \\
\hline G.E.+ 183Fov & 49.02 & $a$ & 4.45 & $a$ & 10.96 & $a b$ & 1.02 & $a b$ \\
\hline M.M.+183Fov & 34.46 & $a$ & 2.88 & $a$ & 4.74 & bc & 0.42 & $b$ \\
\hline G.M. & 49.50 & $a$ & 4.45 & a & 5.85 & bc & 0.75 & $a b$ \\
\hline G.í. & 42.10 & a & 4.15 & a & 7.95 & $a b c$ & 1.29 & $\mathrm{a}$ \\
\hline G.E. & 47.60 & $\mathrm{a}$ & 4.98 & a & 11.54 & $\mathrm{a}$ & 1.15 & $a b$ \\
\hline M.M. & 35.91 & $a$ & 3.27 & a & 8.34 & $a b c$ & 0.76 & $a b$ \\
\hline
\end{tabular}

\section{Sonuçlar}

Mikorizal yaşam büyük ölçüde bitkifungus arasındaki besin alışverişine dayanan ve karşılıklı beslenme ilişkisi içinde yürüyen simbiyotik bir yaşam şeklidir. Bu konuda yapılan çalışmaların büyük çoğunluğu bitki lehine olan beslenme yönüne dikkati çekmişler ve AMF bitkilerin daha iyi geliştiğini ifade etmişlerdir (Rhodes, 1980; Hayman, 1982; Marschner, 1995; Smith and Read, 2008). Nitekim bu çalışmada da üç farklı AMF türü ve bunların karışımı olan mix türünün denemede kullanılan Fov hastalık etmenleri ile birlikte biber fidelerine inokulasyonları sonucunda sürgün boyu, kök boyu, kök boğazı çapı, yaprak sayısı, sürgün yaş ve kuru ağırlık, kök yaş ve kuru ağırlık gibi bazı morfolojik gelişim parametrelerinin genel olarak kontrol bitkilerine göre yüksek değerler aldığı tespit edilmiştir.

AMF Funguslar gerek biyotik gerekse abiyotik stres koşullarına karşı birçok kültür bitkisini olumlu yönde teşvik etmekle beraber son yıllarda yapılan çalışmalar, bitkilerdeki pozitif etkinin, genetik varyasyona bağlı olarak çeşitler arasında farlılık gösterebileceğini göstermiştir (Declerck et al., 1995; Linderman and Davis, 2004; Şensoy et al., 2007). Bu çalışmada da farklı Fov izolatlarının aynı veya farklı AMF'lere tepkileri hem hastalık şiddeti, hem kolonizasyon oranı hem de mikorizal spor yoğunluğu açısından değişkenlik göstermiştir. Nitekim AMF fungusları kök sistemindeki anatomik ve morfolojik değişimler meydana getirerek patojenin enfeksiyon oluşturmasını ve rizosfer interaksiyonlarını etkileyebilmektedirler 
(Azcon-Aguilar and Barea, 1996; Demir and Akköprü, 2007).

Sonuç olarak; Arbüsküler Mikorizal Funguslar, bitki koruma içerisinde özellikle hastalıkların kontrolünde 'yüksek potansiyel etmenler' olarak görülür. Phytophthora, Rhizoctonia ve Fusarium patojenleri tarafından neden olunan bitki hastalıklarına karşı AMF'nin potansiyel biyolojik mücadele elemanı olduğu görülmüştür. Ayrıca, AMF ve biyolojik mücadele elemanları arasında sinerji olduğu kanıtlanmıştır. Bu interaksiyonlar bitkilerde kök salgıları, fitoaleksinler ve fenolik bileşiklerin üretimini teşvik eder. Böylece, AMF bitki ve toprak mikrobiyal aktivitesini etkiler (Biçici, 2011). Dolayısıyla mikorizal fungusların yer aldığı patosistemlerde Fov hastalık şiddetindeki azalışı, mikorizal bitkilerdeki Fosfor ve Potasyum miktarı artışına ve AMF'nin hastalığın etkilerini geciktirmesine bağlayabiliriz.

Bazı konukçu-patojen-AMF fungus kombinasyonlarında başarılı sonuçlar elde edilmesine karşın, bazı sistemlerde hastalık şiddetini artırıcı etkide olması veya doğrudan etkisi olmadığı da bildirilmektedir (Dehne, 1982). Dolayısıyla bugüne kadar çalışılan sistemlerde ki elde edilen sonuçlar arasında farklılık bulunduğundan, tüm bitki patojen sistemlerinde "mikorizal fungusların hastalıklara karşı koruyucu etkisi vardır" şeklinde genelleme yapmak güçtür (Bilgili ve Kavak, 2013).

Bitki hastalıklarını önlemede tarımsal kimyasallara karşı biyolojik mücadelenin gelişimi çevre dostu bir alternatif olarak kabul edilir. Ekseri tarımsal ve orman ürün türlerinin kök sistemleri ile simbiyotik beraberlikler oluşturan mikorizal funguslar 'potansiyel biyolojik koruyucu etmenler' olarak önerilmektedir (Yücel ve ark., 2001; Biçici, 2011). Söz konusu bu varsayım mevcut çalışma sonuçlarını da açıklayıcı niteliktedir.

\section{Ekler}

$\mathrm{Bu}$ araştırma makalesi, Doktora tez çalışmasının bir bölümünden hazırlanmış olup, Doktora projesi olarak TAGEM (Tarımsal Araştırmalar ve Politikalar Genel Müdürlüğü- Proje No: TAGEM-BS13 /09-03 /02-06) ve HUBAK (Harran Üniversitesi Bilimsel Araştırmalar Komitesi- Proje No: HUBAK-13168) tarafından desteklenmiştir.

This research article has been financially supported by TAGEM (General Directorate of Agricultural Research and Politics- Project Number: TAGEM-BS-13 /09-03 /02-06) and HUBAK (Harran University Scientific Research Commision- Project Number: HUBAK13168) as a part of the Ph.D study.

Not: $\mathrm{Bu}$ çalışmanın abstract kısmı ICAFOF Kongresinde (International Conference on Agriculture, Forest \& Food Sciences and Technologies, Cappadocia-TURKEY, 15-17 May 2017) yayınlanmıştır.

Ayrıca çalışmada kullanılan AMF izolat türleri, Prof. Dr. Semra DEMiR- VANYüzüncü yıl Üniversitesi-Bitki Koruma Bölümü kültür stoklarından temin edilmiş olup değerli hocamıza ve bölüm çalışanlarına teşekkür ederiz. 


\section{Kaynaklar}

Abd-Elsalam, K.A., Aly, I.N., Abdel-Satar, M.A., Khalil M.S., Verreet, J.A., 2003. PCR Identification of Fusarium Genus Based on Nuclear Ribosomal-DNA Sequence Data. African Journal of Biotechnology Vol. 2 (4), pp. 82-85, April 2003.

Abd-Elsalam, K.A., Asran-Amal, A., Schnieder, F., Migheli, Q., Verreet, A., 2006. Molecular Detection of Fusarium oxysporum f.sp. vasinfectum in Cotton Roots by PCR and Real -Time PCR Assay. Journal of Plant Diseases and Protection, 113 (1), s.14-19, 2006, ISSN 1861-3829.

Agrios, N.G., 1997. Mycorrhizae. Plant Pathology. Fourth ed., p 404-406.

Ahmed, A.S., Sanchez, C.P., Candela, M.E., 2000. Evaluation of induktion of systemic resistance in pepper plants (Capsicum annum) to Phytophthora capsici using Trichoderma harzianum and its relation with capsidiol acumulation. European Journal of Plant Pathology. 106: 817-824.

Akay, A., Karaarslan, E., 2015. Determining the Effectiveness of Mycorrhizal Inoculation on Increasing the Resistance of Vetch against Different Doses of Nickel. Selcuk J Agr Food Sci, 29 (2): 34-39.

Akköprü, A., Demir, S., 2005. Biological Control of Fusarium wilt in tomato caused by Fusarium oxysporum f. sp. lycopersici by AMF Glomus intraradices and some Rhizobacteria. Journal of Phytopathology. 153 (9): 544-550.

Alejo- Iturvide, F., Marquez- Lucio, M. A., Morales- Ramirez, I., VazquezGarciduenas, M.S., Olalde- Portugal, V., 2008. Mycorrhizal protection of chili plants challenged by Phytophthora capsici. Journal of Plant Pathology, 120(1):13-20, 2008.

Anonim, 2017. Türkiye İstatistik Kurumu verileri. Erişim: www.tuik.gov.tr

Anonim, 2004. Şanlıurfa il Planlama ve Koordinasyon Müdürlüğü verileri, Şanlıurfa.

Anonim, 2008. Şanlıurfa Ticaret ve Sanayi Odası verileri, Şanlıurfa.

Anonymous, 2014. Reports of FAO. Import Health Standard (IHS), Fresh Fruit/Vegetables Capsicum (Capsicum annuum) from Australia (Biosecurity Act 1993),13 June 2014, 11 p.
Aslanpay, B., Demir, S., 2015. Arbüsküler Mikorizal Fungus (AMF) ve Hümik Asitin Biber (Capsicum annuum L.) Bitkisinin Gelişimi ve Phytophthpra capsici Leonian'ın Neden olduğu Kök Boğazı Çürüklüğü Hastalığına Etkileri. YYÜ Tar. Bil. Derg. (YYU J AGR SCI), 2015, 25 (1): 48-57.

Azcon-Aguilar, C., Barea, J.M., 1996. Arbuscular Mycorrhizas and biological control of soil borne plant pathogens-an overview of the mechanisms involved. Mycorrhiza 6: 457464.

Biçici, M., 2011. Bitki hastalık etmenleri ile biyolojik mücadelenin başarısını arttırmada mikorizanın rolü. Türk. Biyo. Müc. Derg., 2011, 2(2): 139-174. ISSN 2146-0035.

Bilgili, A., Kavak, H., 2013. Bitki- Fungal Patojen Etkileşiminde Biyolojik Mücadele Etmeni Olarak Mikoriza Kullanımı. Gıda \& Tarım ve Hayvancılık Bakanlığı, Gıda ve Kontrol Genel Müdürlüğü, Bitki Koruma Ürünleri (Biyolojik ve Biyoteknik Mücadele) Cilt II, 1. Bitki Koruma Ürünleri ve Makineleri Kongresi, 83-103 s., Ankara 2013.

Bilgili, A., Yücel, S., Kavak, H., 2015. Gap Bölgesi Biber Üretim Alanlarında Kurumalara Sebep Olan Toprak Kökenli Funguslar, GAP VII. Tarım Kongresi, 28 Nisan-1 Mayıs 2015, Şanlıurfa.

Bilgili, A., Fidan, H., Yücel, S., Güldür, M.E., 2017.Determination of Mixed Fusarium spp. Infections Causing Dryings in Pepper Growing Areas in the GAP Region of Turkey. International Workshop Plant Health: Challenges and Solutions, Abstract Book, 23-28 April 2017, Antalya-Turkey, p: 59.

Caron, M., Fortin, J.A., Richard, C., 1985. Effect of Glomus intraradices on infection by Fusarium oxysporum f.sp. radicislycopersici in tomatoes over a 12-week period. Canadian Journal of Botany. 64: 552-556.

Declerck, S., Plenchette, C., Strullu, D.G., 1995. Mycorrhizal dependency of banana (Musa acuminate, AAA group) cultivar. Plant and Soil 176: 183-187.

Dehne, H.W. 1982. Interactions Between Vesicular - Arbuscular Mycorrhizal Fungi and Plant Pathogens. Phytopathology, (72): 1115 - 1119

Demir, S., Akköprü, A., 2007. Using of Arbuscular Mycorrhizal Fungi (AMF) for Biocontrol of Soil-borne Fungal Plant Pathogens, pp. 1737, in: Biological Control of Plant Diseases. 
Chincholkar SB, Mukerji KG (eds), Haworth Press, NY, USA.

Demir, S., Ocak, E. Ö, Tüfenkçi, Ş., Şensoy, S., 2012. Arbüsküler Mikorhizal Fungus (AMF), Peyniraltı suyu ve Humik Asit Uygulamalarının Bazı Sebzelerin Yetiştiriciliğine ve Verticillium dahliae Kleb'ın neden olduğu solgunluk Hastalığına Etkileri. Tubitak proje sonuç raporu, Proje No: 1080862, Eylül-2012, Van, 94 s.

Gerdeman, J.W., Nicolson, T., 1963. Spores mycorrhizal endogone species extracted from soil by wet slaving and decanting. Trans. Brit. Mycol. Soc. 42(2), 235-244.

Givonetti, M., Mossea, B., 1980. An evaluation of techniques for measuring vesicular arbuscular mycorrhiza in roots. New Phytologist. 84, 489-500.

Gosling, P., Hodge, A., Goodlass, G., Bending, G.D., 2006. Arbuscular mycorrhizal fungi and organic farming. Agriculture, Ecosystems \& Environment, 113 (1-4): 1735, 2006.

Gülser, E., Tüfenkçi, Ş., Demir, S., 2014. Domateste potasyum, salisilik asit ve humik asit uygulamalarının fide çıkışı ve Fusarium solgunluğuna (Fusarium oxysporum f.sp. lycopersici) etkileri. YYü Tarım Bilimleri Dergisi. 24 (1): 16-22.

Hassan Dar., Zargar G., Beigh M.Y., 1997. Biocontrol of Fusarium root rot in the common bean (Phaseolus vulgaris L.) by using symbiotic Glomus mosseae and Rhizobium leguminosarum. Microbial Ecology 34: 74-80.

Hayman, D., 1982. Influence of soils and fertility on activity and survial vesicular-arbuscular mycorrhizal fungi. Phytopathology 72: 1119-1126.

Jones, J.B., Jones, J.P., Stall, R. E., Zitter, A.T., 1993. Compendium of Tomato Diseases. APS Press. $73 \mathrm{p}$.

Kaçar, B., İnal, A., 2008. Bitki Analizleri. Nobel Yayın Dağıtım, Ankara, 892s. ISBN: 978605-395-036-3.

Linderman, R.G., 1992. Vesicular-Arbuscular Mycorrhizae and soil microbial interactions. Mycorrhizae in Sustainable Agriculture (54): 45-71.

Linderman, R.G., Davis, A.E., 2004; Varied response of marigold (Tagetes spp.) genotypes to inoculation with different arbuscular mycorrhizal fungi. Sci. Hort. 99: 67-78.
Ma, L., Qiao, X., Gao, F.,Hao, B., 2001. Control Of Sweet Pepper Fusarium Wilt With Compost Extracts And Its Mechanism. Chinese Journal of Applied and Environmental Biology. 2001-01. Tab 5, Ref 12: s436.413.

Marschner, H., 1995. Mycorrhizas. Mineral Nutrition of Higher Plants, 2nd ed., Academic Press., London.

Matsubara, Y., Tamura, H., Harada, T., 1995. Growth enhancement and Verticillium wilt control by Vesicular- Arbuscular Mycorrhizal Fungus Inoculation in Eggplant. J. Japan Soc. Hort. Sci. 64 (3):555561.

Mule, G., Susca, A., Stea, G., Moretti, A., 2004. Spesific Detection of the Toxigenic species Fusarium proliferatum and F. oxysporum from Asparagus Plants Using Primers Based on Calmodulin Gene Sequences. FEMS Microbiology Letters 230 (2004) 235-240.

Ortaş, i. 1998. Toprak ve bitkide mikoriza. Workshop. Ç.Ü.Z.F. Toprak Bölümü, 20-22 Mayıs 1998. $61 \mathrm{~s}$.

Ortaş, i. 2003. Effect of selected Mycorrhizal Inoculation on Phosphorus sustainability in sterile and nonsterile soils in Harran Plain in South Anatolia, Journal of Plant Nutrition, 26 (1): 1-17, 2003.

Özgönen, H., Biçici, M., Erkılıç, A., 1999. The effect of salicyvlicacid and endomycorrhizal fungus Glomus etunicatum on plant development of tomatoes and Fusarium wilt caused by Fusarium oxysporum f.sp. lycopersici. Turkish Journal of Agriculture and Forestry 25: 25-29.

Perpetua, N.S., Monares, D.P., 1998. Host plants and pathogen race of Fusarium oxysporum F. sp. vasinfectum. Philippine Journal of Crop Science, Supplement no.1, Crop protection newsletter, ISSN: 0115-463X, Volume: 23, p: 36.

Phillips, J.M., Hayman, D.S., 1970. Improved Procedure for Cleaning Roots and Staining Parasitic and Vesicular- Arbuscular Mycorrhizal Fungi for Rapid Assement of Infection. Trans Br. Mycol. Soc., 55, 158161.

Read, D.J., Kouckeki, N.K., Hodgsen, J. 1976. Vesicular arbuscular mycorrhizae in natural vegatative system. The occurrence of infection. New Phytol. 77, 641-653.

Rhodes, L.H., 1980. The use of mycorrhizae in crop production systems. Outlook on Agriculture 10(6): 275-281. 
Smith S.E., Read, D.J., 2008. Mycorrhizal Symbiosis 2nd ed., Academic Press, London.

Song, H., 2005. Effects of VAM on host plant in the condition of drought stress and its mechanism, Electronic Journal of Biology, 1 (3): 44-48, 2005.

Şensoy, S., Demir, S., Türkmen , Ö., Erdinç, Ç., Savur, O.B., 2007. Responses of some different pepper (Capsicum annuum L.) genotypes to inoculation with two different arbuscular mycorrhizal fungi. Scientia Horticulturae 113: 92-95.

Tutar, F. K., 2014. Patlıcanda Solgunluk Hastalıkları (Verticillium dahliae ve Fusarium oxysporum f.sp. melongenae) 'na karşı Mikorizal Fungusların ve Abiyotik Uyarıcıların Etkilerinin Belirlenmesi. Çukurova Üniversitesi Fen Bilimleri Enstitüsü Bitki Koruma Anabilim Dalı, Doktora tezi, Adana-2014, 77 s.

Varma R.S., George, K.J., Balaji, S., Parthasarathy, V.A., 2009. Differential induction of chitinase in Piper colubrinum in response to inoculation with Phytophthora capsici, the cause of foot rot in black pepper. Saudi Journal of Biological Sciences. 16:11- 16

Vosatka, V., Gryngler, M., 1999. Treatment with Culture Fractions from Pseudomonas putida Modifies the Development of Glomus fistulosum Mycorrhiza and the Response of Potato and Maize Plants to Inoculation. Applied Soil Ecology, 11, 245251.

Wang, J., Liang, J., Chen, Y., Gao, J., Zhang, Z., 2005. Inhibition of capsaicin on hyphal growth of Fusarium oxysporum f. sp. vasinfectum and its effects on the protective enzymes activity of pepper plant. Acta Phytopathologica Sinica, 2005S1, S641.3;S432.4.

Yao, M.K., Tweddell R.J., Dẻsilets, H., 2002. Effect of two vesicular-arbuscular mycorrhizal fungi on the growth of micropropagated potato plantlets and on the extent of disease caused by Rhizoctonia solani . Mycorrhiza, 23:1-14.

Yücel, S., 1995. A Study on Soil Solarization and Combined with Fumigant Application to Control of Phytophthora Crown Blight (Phytophthora capsici Leonian) on Peppers in the East Mediterranean Region of Turkey. Crop Protection. 14(8):653-655.

Yücel, S., Elekçioğlu, İ. H., Özgönen, H., Toktay, H., Ortaş, i., 2001. Seralarda Fungal Kök Hastalıklarına ve Kök-Ur Nematodlarına Karşı Solarizasyon ve Mikorizal Fungus Kombinasyonlarının Etkilerinin Araştırılması. Türkiye $\mathrm{XI}$. Fitopatoloji Kongresi Bildirileri,421-431, Eylül 2001, Tekirdağ.

Yücel, S., Özarslandan, A., 2014. Toprak Kökenli Patojenler ve Nematodlar, Toprak Dezenfeksiyonu için Uygulamaların Tanıtımı, Uygulanma Şekilleri. Gıda, Tarım ve Hayvancılık Bakanlığı, Biyolojik Mücadele Araştırma İstasyonu Yayınları Adana-2014, $18 \mathrm{~s}$.

Zambolim, L., Schenck, N.C., 1983. Reduction of the effects of pathogenic, root-infecting fungi on soybean by mycorrhizal fungus Glomus mosseae. Phytopathology, 73: 1402-1405. 